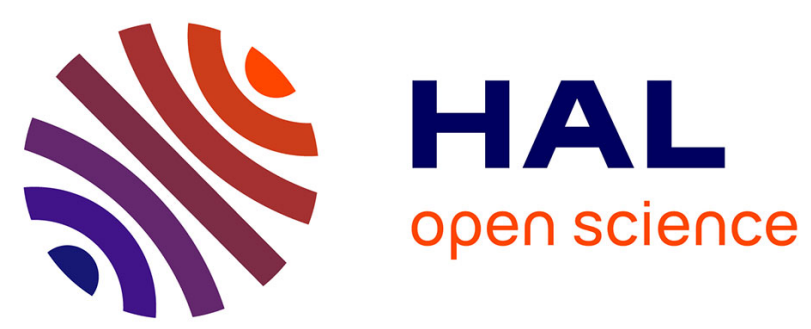

\title{
FACTORS OF CRACK INITIATION AND MICROCRACK PROPAGATION IN ALUMINUM LITHIUM 2091 AND IN ALUMINUM 2024
}

L. Farcy, C. Carre, M. Clavel, Y. Barbaux, D. Aliaga

\section{- To cite this version:}

L. Farcy, C. Carre, M. Clavel, Y. Barbaux, D. Aliaga. FACTORS OF CRACK INITIATION AND MICROCRACK PROPAGATION IN ALUMINUM LITHIUM 2091 AND IN ALUMINUM 2024. Journal de Physique Colloques, 1987, 48 (C3), pp.C3-769-C3-775. 10.1051/jphyscol:1987390 . jpa00226622

\section{HAL Id: jpa-00226622 https://hal.science/jpa-00226622}

Submitted on 1 Jan 1987

HAL is a multi-disciplinary open access archive for the deposit and dissemination of scientific research documents, whether they are published or not. The documents may come from teaching and research institutions in France or abroad, or from public or private research centers.
L'archive ouverte pluridisciplinaire HAL, est destinée au dépôt et à la diffusion de documents scientifiques de niveau recherche, publiés ou non, émanant des établissements d'enseignement et de recherche français ou étrangers, des laboratoires publics ou privés. 
FACTORS OF CRACK INITIATION AND MICROCRACK PROPAGATION IN ALUMINUM LITHIUM 2091 AND IN ALUMINUM 2024

\author{
L. FARCY* ${ }^{*}$ C. CARRE, M. CLAVEL ${ }^{*}$, Y. BARBAUX and D. ALIAGA \\ Aérospatiale, Laboratoire Central, 12, Rue Pasteur. \\ F-92152 Suresnes Cedex, France \\ "Université de Technologie de Compiègne, CNRS-UA 849, B.P. 233, \\ Rue $P$. de Roberval, F-60206 Compiègne Cedex, France
}

\begin{abstract}
Initiation and microcrack propagation stages were investigated by optical microscopic observations of fatigue damage. The differences observed at high fatigue lives on $\mathrm{S}-\mathrm{N}$ curves are found to correlate with the nature of initiation sites. It is shown that microcrack growth rates are equivalent for both 2024 T351 and 2091 T8 alloys, though long crack growth rates for $2091 \mathrm{~T} 8$ are lower as compared to those of 2024 T351.
\end{abstract}

\title{
Introduction
}

Due to economic reasons, materials for aerospace applications are selected such that the weight of the structures is kept as low as possible without any loss in the reliability which is required. In addition to high mechanical properties, good fatigue behavior is very often required in aeronautical component design. So, it is interesting to examine whether new AL-LI alloys, which offer a lower density and a higher modulus than conventional aluminum alloys, possess this quality.

The subject of this study is to test the fatigue behavior of 2091 T8 alloy in comparison with the 2024 T351 alloy currently used in aircraft components . Fatigue lives of both materials are compared by analysing successively the crack initiation stage and the stage of short crack propagation.

\section{Materials and experimental procedure}

Two $2 \mathrm{~mm}$ thick plates of aluminum alloy, of composition (wt\%) shown in table 1, were investigated: a 2091 plate in the T8 temper aged condition (T3 $+12^{\mathrm{h}} 135^{\circ} \mathrm{C}$ ) and a conventional $2024 \mathrm{~T} 351$ plate. Room temperature mechanical properties are listed in table 2 .

The intermetallic constituent particles, visible in the optical microscope,were qualitatively identified by energy dispersive $X$ ray analysis and ionic microprobe. Referring to the litterature $(1,2)$, they were recognized as :

- $\mathrm{Al}_{12}(\mathrm{FeMn})_{3} \mathrm{Si}_{2} ; \mathrm{Al}_{2} \mathrm{CuMg} ; \mathrm{Al}_{2} \mathrm{Cu}$ in 2024

- $\mathrm{Al}_{7} \mathrm{Cu}_{2} \mathrm{Fe} ;(\mathrm{Al}, \mathrm{Cu}, \mathrm{Li}, \mathrm{Mg})$ phase in 2091 
A quantative estimation of the particle density showed that the total number of intermetallic particles in 2024 T351 was ten times greater than in 2091 T8 and there was a ratio of three between $\mathrm{Al}_{12}(\mathrm{FeMn})_{3} \mathrm{Si}_{2}$ and $(\mathrm{Al}, \mathrm{Cu}, \mathrm{Li}, \mathrm{Mg})$ phase numbers .

Table 1: Chemical composition (wt \%)

$\begin{array}{llllllllll}\mathrm{Cu} & \mathrm{Li} & \mathrm{Mg} & \mathrm{Mn} & \mathrm{Si} & \mathrm{Fe} & \mathrm{Ti} & \mathrm{Zn} & \mathrm{Zr} & \mathrm{Cr}\end{array}$

$\begin{array}{llllllllllll}2024 & \text { T351 } & 4.6 & - & 1.45 & 0.63 & 0.10 & 0.21 & 0.04 & 0.10 & 0.02 & 0.01 \\ 2091 \text { T8 } & 1.85 & 1.90 & 1.20 & - & 0.02 & 0.02 & 0.02 & - & 0.07 & -\end{array}$

Table 2 : Mechanical properties in longitudinal direction

$\begin{array}{lccc} & \begin{array}{c}\text { Yield strength } \\ (\mathrm{MPa})\end{array} & \begin{array}{c}\text { U.T.S } \\ (\mathrm{MPa})\end{array} & \begin{array}{c}\text { Elongation } \\ (\%)\end{array} \\ 2024 \text { T351 } & 360 & 490 & 20 \\ 2091 \text { T8 } & 330 & 430 & 17\end{array}$

Initiation and propagation of fatigue microcracks were observed on a flat specimen (named A.M.specimen) which was lightly notched in its center in order to minimize the area to be observed (fig.1). The notch was mechanically polished using $1 \mu \mathrm{m}$ diamond paste. The corresponding stress concentration factor $(\mathrm{Kt}=$ local stress at the notch root $/$ nominal stress $;$ nominal stress $=$ F/h.e ; fig.1) calculated by the finite element method was about 1,6 .

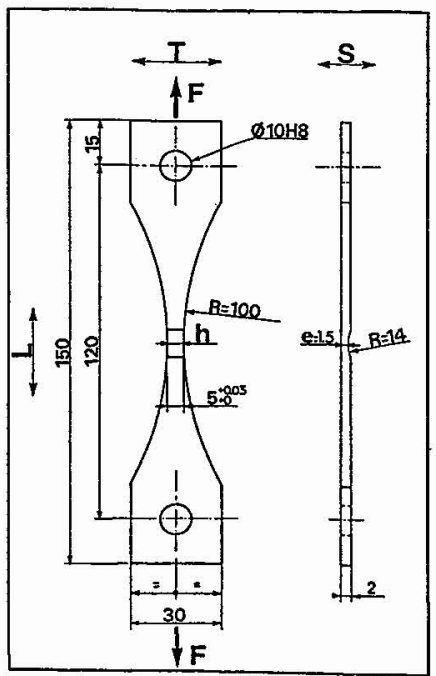

Fig .1 A.M. specimen

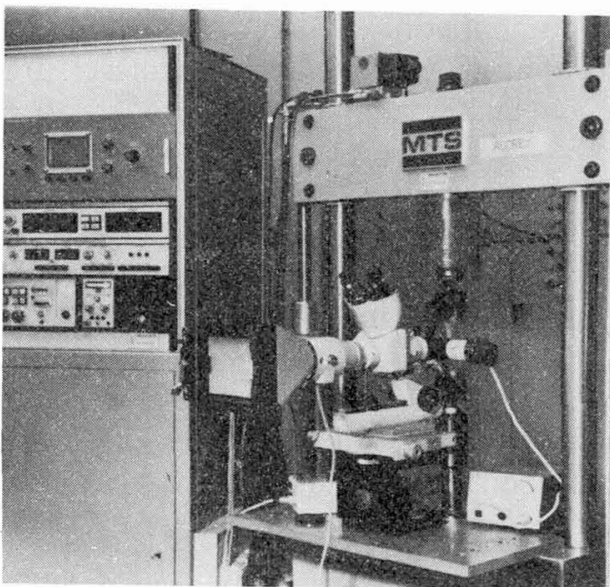

Fig .2 Optical microscope mounted on the M.T.S machine 
Tests were conducted at room temperature in air, on a $\pm 15 \mathrm{kN}$ M.T.S. fatigue machine, at a frequency of $20 \mathrm{~Hz}$. The constant amplitude loading was in tension-tension ( $\mathrm{R}=0.1, \mathrm{R}=\mathrm{F}_{\min } / \mathrm{F}_{\max }$ ) with the stress direction parallel to the rolling direction. An optical microscope with 250 and 640 magnifications was mounted on a $x-y$ micrometer which was attached to the M.T.S machine as shown in figure 2 .

Long crack growth tests were performed on compact center tension specimens, with $R=0.1$, in $L-T$ direction .

\section{Results}

Damage was investigated over fatigue lives ranging from $\mathrm{Nr}=30,000$ cycles to $\mathrm{Nr}=10^{7}$ cycles ( $\mathrm{Nr}$ is the number of cycles to failure). The optical observations on A.M.specimens, which allowed the detection of cracks of length greater than $10 \mu \mathrm{m}$, indicated that all cracks nucleated at surface constituent particles; the size of these particles was found greater than $3 \mu \mathrm{m}$ - These are identified as $\mathrm{Al}_{12}(\mathrm{FeMn})_{3} \mathrm{Si}_{2}$ in 2024 alloy(fig. 4 a) and (Al,Cu, Li, Mg)phase in 2091 alloy (fig. 4 b). Two mechanisms were observed either the particle cracked or there was matrix-particle interface debonding . After initiation, many cracks started to grow and finally met leading to failure. Furthermore, more cracks developed in 2091 than in 2024 for the same applied stress. This is illustrated in table 3 .

$$
\mathrm{S}=260 \mathrm{MPa} \text { * } \quad \mathrm{S}=225 \mathrm{MPa} \text { * }
$$

$\begin{array}{lllll}\text { number of } & 2024 \text { T351 } & 2091 \text { T8 } & 2024 \text { T351 } & 2091 \text { T8 }\end{array}$ cycles

$\begin{array}{rrrrr}30,000 & 10 & 26 & 1 & 6 \\ 50,000 & 14 & 35 & 2 & 16 \\ 80,000 & 16 & 35 & 2 & 21\end{array}$

Table 3 : Number of microcracks detected by optical microscopy during fatigue tests

${ }^{*} S=F_{\max } /$ h.e

It has to be noted that in 2091 alloy many $(\mathrm{Al}, \mathrm{Cu}, \mathrm{Li}, \mathrm{Mg})$ phase particles broke without crack propagation into the matrix .

Both S-N curves (fig.3) plotted from these test data show a similar behavior at $\mathrm{Nr}<10^{5}$ cycles and a lower fatigue limit is observed for 2091 alloy. 


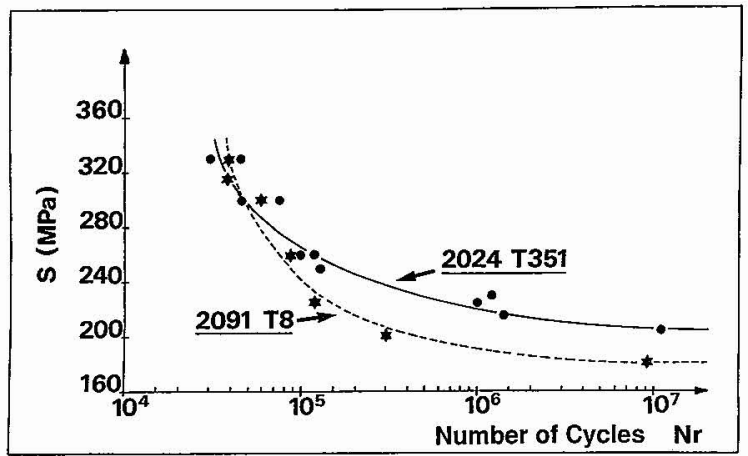

Fig.3 $\mathrm{S} \cdot \mathrm{N}$ curves of $2024 \mathrm{~T} 351$ and $2091 \mathrm{~T} 8, \mathrm{R}=0.1$

Fig. $4 \mathrm{a}$ and $4 \mathrm{~b}$ show the variation of surface crack length (2a) versus number of cycles, at $S=260 \mathrm{MPa}$ which corresponds to fatigue lives of about $10^{5}$ cycles. Taking into account the large number of cracks in a specimen, only some representative ones are presented. Some initiated microcracks were observed to become non-propagating. They stopped either at a grain boundary or in the matrix (by local unloading or interaction with the microstructure under the surface).
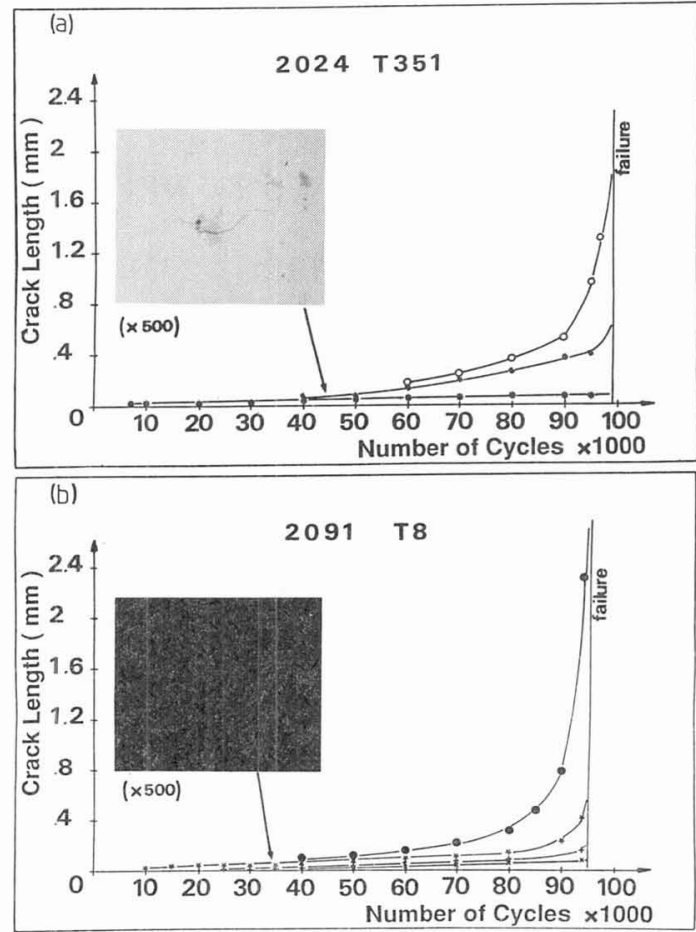

Fig.4 Initiation and propagation behavior of microcracks in 2024 T351 (a) and in 2091 T8 (b)

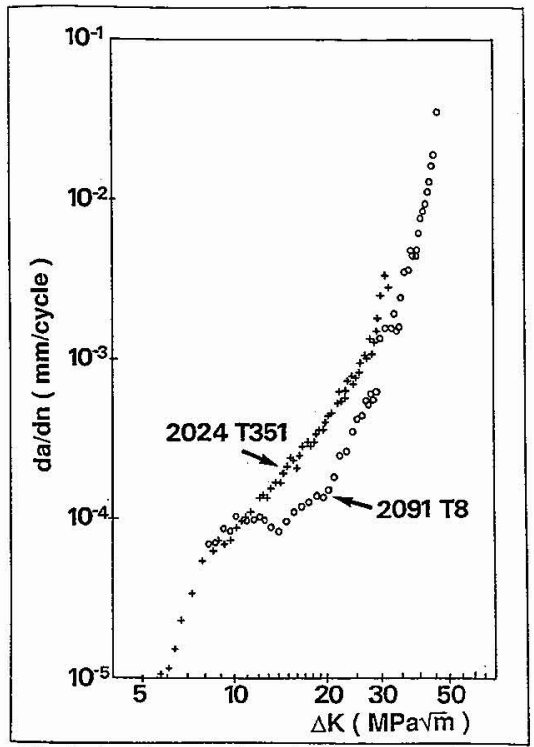

Fig.5 Crack growth rates versus stress intensity factor range, at $R=0.1$

Long crack growth results are shown on figure 5 . The growth rate for $2091 \mathrm{~T} 8$ is significantly lower as compared to those of 2024 T351 in the range $10^{-4} \mathrm{~mm} /$ cycle $<\mathrm{da} / \mathrm{dn}<10^{-3} \mathrm{~mm} /$ cycle . 


\section{Discussion}

Concerning initiation mechanisms, it is interesting to note that more microcracks are generated in 2091 T8 alloy than in 2024 T351 alloy though the number of intermetallic constituent particles is lower. The origin of this difference may be sought in intermetallic compound compositions; the brittleness of (Al,Cu, Li, Mg) phase particles seems to be greater compared to $\mathrm{Al}_{12}(\mathrm{FeMn})_{3} \mathrm{Si}_{2}$ or the particle-matrix interface is more brittle in 2091 alloy . This assumption is supported by works in progress in our laboratories which show that, at very low strain or stress, sinuous deformation modes could be observed. In our opinion, these deformation modes have a little influence on microcrack mechanisms.

This assumption is also in agreement with test results : in each alloy, only one kind of particles induce damage .

To explain the S-N curves of both alloys (fig.3), we have divided the following discussion into two parts :

\section{$-\mathrm{Nr} \leq 10^{5}$ cycles $(\mathrm{S} \geq 260 \mathrm{MPa})$}

In this work, we consider that the initiation stage corresponds to the number of cycles ( $\mathrm{Na}$ ) necessary to generate the first microcrack observable by optical microscopy. Its length is in every case in the range of 10 to $20 \mu \mathrm{m}$

If we plot $S$ versus $\mathrm{Na} / \mathrm{Nr}$ ratio (fig.6) we observe for both materials that initiation occurs in the early stage of the life time. This fact appears also on the curves of figure 4 : initiation occurs during the first ten percent of total life ; therefore short crack propagation is predominant. For instance, about 80 $\%$ of total life is concerned with propagation up to a length of $200 \mu \mathrm{m}$.

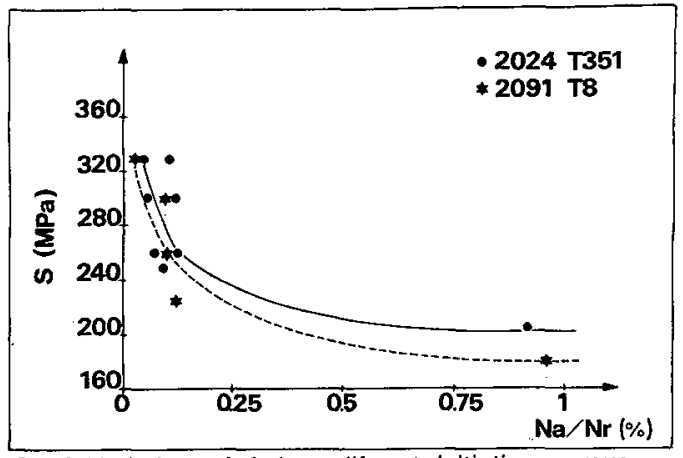

Fig.6 Variation of fatigue life at initiation versus applied stress at $R=0.1$

For a better understanding of microcrack propagation behavior, we transposed the data on to curves giving crack growth rates as a function of surface crack mid-length (fig.7). These are made up of series of deceleration and acceleration periods between $10^{-7} \mathrm{~mm} /$ cycle and $10^{-5} \mathrm{~mm} /$ cycle up to a 
crack length of approximately $2 a=200 \mu \mathrm{m}$. This behavior has already been observed in previous works $(3,4,5)$. Retardation of crack advance occurs when a crack tip approaches a microstructural feature (predominantly grain boundaries). The figure 7 shows similar microcrack growth rates for both 2024 T351 and 2091 T8 alloys.

Thus, we can see that the initiation and microcrack propagation stages are equivalent at $\mathrm{Nr} \leq 10^{5}$ cycles, which explains the equal fatigue lives to failure .

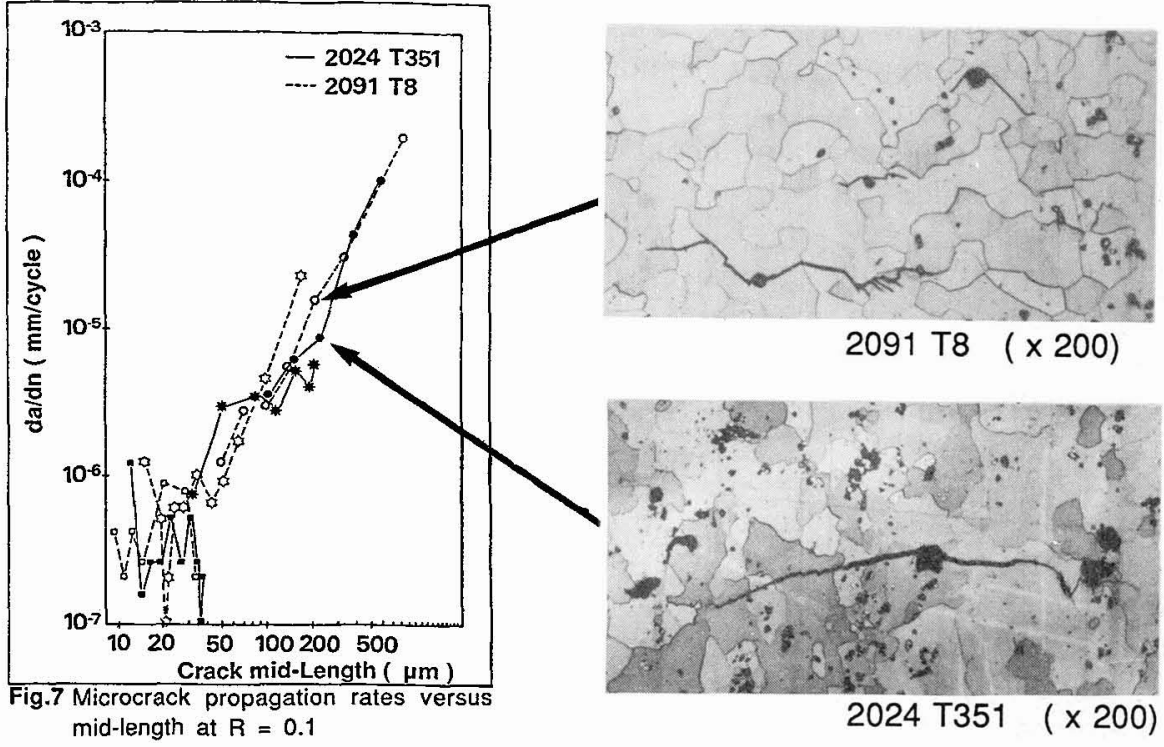

On the other hand, microcrack growth rates are similar for both materials though the long crack growth rates are very different. A possible explanation is that closure effect, which is important at $R=0.1$ for long cracks becomes negligible for short cracks. This is supported by recent studies $(6,7)$.

\section{$-\mathrm{Nr}>10^{5}$ cycles $(\underline{S<260 \mathrm{MPa}})$}

At $\mathrm{S}<260 \mathrm{MPa}$, fatigue damage is predominantly induced by crack initiation. This is supported by the two following points : firstly, $\mathrm{Na} / \mathrm{Nr}$ ratio increases rapidly when the applied stress decreases ; secondly, on each material, several tests were conducted at stresses below the fatigue limit ( $\mathrm{Nr}>10^{7}$ cycles ). After many optical observations during the test, no microcracks have been detected, contrary to observations made by some authors (5) .

Therefore, the lower fatigue limit of 2091 compared to 2024, as determined by our experiments on A.M.specimens, may be due to the apparent greater brittleness either of the $(A l, C u, L i, M g)$ phase particles or of the interface between these particles and the aluminum matrix. 


\section{Conclusions}

This research shows that fatigue crack initiation and microcrack propagation stages are equivalent for $2091 \mathrm{~T} 8$ and $2024 \mathrm{~T} 351$ alloys, at $R=0.1$ and at low fatigue lives ( $\mathrm{S}>260 \mathrm{MPa}$ ).

In both alloys, the initiation of microcracks occurs either at cracked particles or at the matrix-particle interface ; these particles are identified as (Al,Cu,Li,Mg) phase in $2091 \mathrm{~T} 8$ and $\mathrm{Al}_{12}(\mathrm{FeMn})_{3} \mathrm{Si}_{2}$ in $2024 \mathrm{~T} 351$.

The lower fatigue limit of 2091 alloy, observed in this work, can be explained by a greater brittleness of initiating particles.

Long crack growth results show a better crack growth resistance of $2091 \mathrm{~T} 8$ at $\mathrm{R}=0.1$.

This study shows encouraging fatigue results for 2091 T8 alloy compared to 2024 T351 alloy. For a better knowledge of the 2091 fatigue behavior, it would be necessary to continue this work by fatigue tests under variable amplitude loadings.

\section{Acknowledgements}

This work has been carried out with the financial support of the D.R.E.T .

\section{References}

(1) Metallography,structures and phase diagrams, Metal Handbook, pp. 120-129 .

(2) SMITH, A.F., Aluminium Lithium Alloys III, The Institute of Metals, London, U.K., 1986, pp. 164-172

(3) LANKFORD, J. (1985) Fatigue Fracture Engng Mater. Structures, 8 , pp.161-175.

(4) BLOM, A.F., FATHULLA, A., HEDLUNG, A., STICKLER, R., and WEISS, B. (1986) The behavior of short fatigue cracks (Edited by K. J. Miller and E. R. de los

Rios), (Mechanical Engineering Publications, London), pp. 37-66.

(5) FATHULLA, A., WEISS, B., and STICKLER, R. (1984) International spring meeting of SOCIETE FRANCAISE DE METALLURGIE , pp. 182-195

(6) VENKATESWARA RAO, K.T., YU, W., and RITCHIE, R.O., (1986) Scripta Met. , $20, \mathrm{pp} .1459-1464$

(7) SURESH, S. and RITCHIE, R.O. (1983) Mater. Sci. Engng , 57 , p.227 